\title{
The Ubiquitous Violence: A Socio-anthropology of Incivility Between Pupils in a School Environment in the City of Ouagadougou (Burkina Faso)
}

\author{
Zakaria Soré \\ Sociology Department, University Joseph Ki-Zerbo, Ouagadougou, Burkina Faso \\ Email address: \\ sorefils@gmail.com, zakaria1.sore@ujkz.bf \\ To cite this article: \\ Zakaria Soré. The Ubiquitous Violence: A Socio-anthropology of Incivility Between Pupils in a School Environment in the City of \\ Ouagadougou (Burkina Faso). Social Sciences. Vol. 10, No. 4, 2021, pp. 172-178. doi: 10.11648/j.ss.20211004.12
}

Received: May 19, 2021; Accepted: June 15, 2021; Published: July 13, 2021

\begin{abstract}
Background: The Burkinabè School faces many cases of violence. Acts of violence between students or between students and supervisors are legion. In a few years, School has become more and more a privileged space for the violence of various kinds, thus compromising its mission of socialization and transmission of knowledge and social norms. The violence is maintained by "lace wars", the consequences of which are the reduction of "civilities" in the school environment. The students develop new forms of rivalry and alliances, and there is a rise in rivalries between gangs, which can turn into more or fewer fights with the use of weapons. This configuration of relationships between students feeds punitive expeditions between groups of students and/or schools. The spirit of self-justice took precedence over the use of the crisis management system existing in schools. The objective of this research is to understand the logic of incivility in schools, their manifestation, and actors' representations. To achieve the research objectives, we opted for an anthropological approach. The anthropological approach led us to immerse ourselves in school life in the city of Ouagadougou. This "proximity" with people experiencing the issue of violence made it possible to observe students' living together in several high schools in Ouagadougou. Interviews with student, victims and actors of violence, leaders of student groups, school officials, supplemented the observation. It emerges from this research that the school environment in the city of Ouagadougou is made up of ritualized transgressions, which take place during demonstrations and student strikes but also during the publication of school results. Violence manifests itself through racketeering. To protect themselves, the victims try to retaliate by resorting to clans. The clans become protective bodies and animators of violence in the school environment.
\end{abstract}

Keywords: Violence, School Environment, Intergroup Rivalries, Social Changes

\section{Introduction}

There is violence everywhere in society [1]. It is an omnipresent phenomenon in any society; it mainly affects society and is inherent in people [2]. This reality does not spare the school environment where incivilities are permanent and different actors: students, teachers, and administrative staff. Violence and incivility at school refer to various anti-social behaviors: insults, taunts, pushes, noises, smells. They extensively participate in the climate of indiscipline and tension that one frequently encounters in middle and high schools, an environment, which do not depend only on offences retained at the judicial level [3].

In 2002, the National Assizes in Burkina Faso's General
Report on education noted an upsurge in schools and universities' insecurity. Acts of violence and incivility mark relations between schoolchildren. Charlot and Emin [4] made the same observation when they assert that "what has increased in the school universe is first and foremost the daily tension much more than the violence understood as physical aggression. This tension maintains and exacerbates incivility and explodes in crises, insults, fights, beatings. "There is so much writing about violence in schools today that A. Barrère [5] thinks that this theme has, in many ways, replaced the canonical discourse on the drop in educational attainment. Although these acts are a concern nowadays, J. D. Lompo [6] believes that there is a dynamic of overestimating violence in schools, which leads some 
scholars to prefer to talk about incivility.

These acts of incivility, qualified as school violence, manifest themselves in various forms. Authors [4] proposes a classification of violent demonstrations at school related to the relational climate: verbal interactions (shouts, insults, altercations); repeated incidents suggesting proximity hatred; assaults on-premises, cars, and racketeering. Violence is physical, verbal and can target various actors in school life. The protagonists of school violence are numerous and include students, teachers, school officials, and students' parents.

This research aims to understand the socio-educational context that contributes to fuel violence in Ouagadougou's school environment. In this article, we approach violence with a certain distance, especially considering [6] warnings, which invites us to come to the question of school violence outside the sensational vision. We get out of this trap of the vice between dramatizations or excess and negation in a particular cultural universe, approach the fact from a distant description of the reality of the establishments, and approach these practices ranged under the influence of school violence as social facts. Two main points structure the paper: the research methodology and the findings, which include three points: social elements favoring violence, manifestations of incivility in the school environment, and the development dynamics of clans in this context of pervasive incivility.

\section{Methodology}

The research objective is to understand the logic of incivility in schools, their manifestation, and actors' representations. The anthropological survey was the most suitable approach for this reason. Thus, we combined interviews and direct observation of interactions between students in classes, during breaks, and on their way to school. The approach consisted of giving the floor to the actors. Thus, students, teachers, and administrative officials of the survey's establishments shared their schools' incivility experiences. We conducted Interview guides and life story guides with students, teachers, and administrative staff of these establishments. I organized focus groups. The focus groups' objective was to provoke contradictory debates between the actors on the theme to bring out "what everyone knows and which no one talks" [7]. This strategy has made it possible to collect anecdotes and experiences of perpetrators and victims of incivilities in schools. The literature review supported this empirical work and provided an overview of the literature on violence in schools.

The survey took place in ten public and private schools in Ouagadougou between December 2015 and March 2016. It concerned both post-primary and secondary education. In total, thirty-seven individual interviews, life stories, and five focus groups were carried out.

\section{Violent Ritualized Transgressions}

The violent ritualized transgression refers to students' behaviours at particular times in school life and national political life. School rites such as strikes and other school events produce incivilities.

\subsection{The Moments of Strikes, Occasions of Violence Between Students}

Even if the school has absolute autonomy, it remains that it operates globally and draws its conduct. In this sense, the acts of violence that we observe in school constitute a sort of extension of society's violence. Since the end of the 1990s, Burkina Faso has experienced numerous socio-political crises echoed in schools. If political governance had made it possible to muzzle opposition political parties and to have the backing of traditional and religious institutions, pupils and students have positioned themselves as the main force of protest. Moreover, several researchers [8] have shown that pupils and students have been the spearhead of many fights against impunity Burkina Faso. They effectively animated the protest forces in the essential political turns of the country. The Association of Pupils and Schoolchildren of Ouagadougou (AESO) dominates Ouagadougou's school union movement, affiliated with the National Association of Burkinabè Students (ANEB). Both claiming to be class struggle unionism, ANEB and AESO stand in solidarity with each other in times of struggle. At the national level, following the assassination of Norbert Zongo, ANEB joined the Collective of Democratic Organizations of the Masses and Political Parties (CODMPP) and engaged its activists in the fight against impunity. This proximity between the school movements and the political parties of the opposition and civil society-led the pupils to find themselves in the fighting and maintained a permanent dynamic of protest. Universities and the secondary school received the collective calls to demonstrate as calls to cease all academic and school activity. In carrying out strike slogans, members of trade union structures use symbolic, psychological, and often even physical violence to get other students to follow suit, as I. Sory [9] points out:

During these violent protests, many students were assaulted. For example, on January 17, 2000, following the refusal of certain students to follow the striking slogan of the National Union of Students of Faso (UNEF), some of the militants of this union, armed with knife sticks and machetes did not hesitate to assault and injured students.

Schoolchildren cannot tolerate other comrades being left out during strikes to demand justice in blood crimes and economic crimes. More often than not, the schools, which are reluctant to follow the strike movements, are private establishments, which popular opinion regards as establishments that welcome children from the upper classes. A kind of war is developing against these students considered privileged and who refuse to share the popular masses' struggles. For example, groups of strikers target establishments considered "cake" establishments that refuse to follow the movements and force them to respect the strike slogans. P. Bianchini and G. Korbéogo [8] show that the term "cakes" is pejorative and is "sometimes used to designate 
students from wealthy backgrounds or close to the party in power, reluctant to engage in industrial action." These students are seen as traitors, if not smart kids who want to take advantage of the situation to get ahead of the other students. Moreover, disrupting the course is also part of the strategies of levelling the progression of the classes. Thus, the students of the high schools affected by the strikes are driven both by logic to prevent educational activities in other institutions so that they are at the same level of learning and punish students who refuse to go on strike. The logic of preventing lessons from taking place in private schools is a strategy for students who consider themselves part of the disadvantaged class, not allowing others to continue their domination in society easily.

The principle of strike leaders in schools is to make no concessions to those who refuse to join the movement. Thus, they use violence to bring out their fellow students who do not respect the strike movements.

When they come, we have to go out. They do not like school; they ride motorcycles in the schoolyard, honk, and whistle. To get the others to get out of class quickly, they throw stones on the roofs, go back to level and threaten those who do not want to go out. When they return to class, they can wet the rag with water and swing it at the students to get them out. [Interview, student in high school, Wend Lamita private school complex, January 2016].

These demonstrations' key moments are the anniversary dates of students' assassinations and human rights defenders in Burkina Faso. Our immersion in the school environment made it possible to see, especially in December, packs of students on mopeds that rush towards establishments and forcing their comrades to observe the strike movements. During these movements, anyone in the school who opposes striking may face violence. As stated by a teacher-temporary worker in many private schools in Ouagadougou:

During the strike commemorating Norbert Zongo's death, the strikers arrived at an establishment in which I work. When they came, as the students were in composition, the Principal tried to negotiate an hour, the time for the students to finish the first tests before leaving. The strikers took this behavior badly and attacked him directly by throwing stones. He saved his life thanks to his legs' strength, and the students have to leave the classroom after receiving stones on the roofs. [Interview, January 2016].

The strikers do not hesitate to violate the premises of establishments that do not respect the movement to get the others out of the classroom. They do so despite the existence of Decree $\mathrm{n}^{\circ}$ 2016-926 / PRES / PM / MATDSI / MJDHPC / MINEFID / MENA of October 3, 2016, on the protection of the school domain, article $\mathrm{n}^{\circ} 5$ of which specifies that "the school domain is inviolable. No individual other than learners, teachers, and staff who work in educational structures may enter them at any time without authorization, which they should get from the first person in charge of the educational facility for purposes related to school life. ". Once inside the school, the students there are victims of all forms of violence. The Journal "L'Economiste" du Faso reports a school principal's words whose establishment was the target of student strike leaders.

They came and practically broke the office of the censor and the director of studies. That day, our children did not want to let it go because they realized they were losing classes while others were early. The older students decided to discuss with them to reason with them. However, the attackers refused, and in the altercations, students were injured. Counsellors who stood between the armed gang and the students were wounded. Among the strikers, too, some were injured. (l'economiste du Faso.bf/2019/02/18/crise-del'education-Les-establishments-prices-touches-par-laviolence, consulted on March 5, 2020).

This remark shows that strikers violate establishments that do not respect strike movements and that punitive raids can turn into clashes between those who want to observe the strike and those who wish to continue classes.

Violent attitudes towards students who refuse to go on strike often continue in neighborhoods. In these out-of-school spaces, the violence is physical, verbal and psychological. There are taunts against these students, and the term used to refer to them is "cakes". It is also ironic that they are called "good students who love school". The objective of this behavior towards non-strikers is to touch their pride to get them to join the strike movements. The targets of these taunts may retaliate, and this leads to physical clashes. Alongside this repercussion of national socio-political struggles on violence at school, we can also observe that the school institution's functioning through students' classification gives rise to forms of violence against students' special categories.

\subsection{When the School Classification Exposes the Owners of Cultural Capital to Violence}

In the Burkinabè school system, classification still occupies an important place. At the end of each term, the school invites students' parents to learn about their children's results. While in some schools, parents take students' report cards directly, in others, the results are given publicly and in front of the entire educational community. This ritual can expose some pupils to acts of violence as revealed by a pupil of the third year of high school of the private high school Wendso:

"After the results, the big ones who are not well-classified start to tell you," ah so you are the most strong what "? They say this to make a fool of you. If you reply they are going to hit you, and they tell you that you are only strong in school, if not nothing." [Interview, January 2016].

There are indeed groups in the school environment that does not like students who stand out in their academic performance. After the compositions' results, teachers praise the "good pupils" during the lessons, and they become models. Simultaneously, the counter-examples are taken from the "bad students" who hold the ranking tail. In the logic of teachers and students, the concept "good students" reflects the benchmark, what to be. Some students who do not receive words of encouragement want to show good students that there are areas 
in which they, too, could be awarded. Thus, good students are the object of verbal, if not physical, assault in schoolyards. This behavior towards "intellectuals" softens the pride of having good grades [10]. These behaviors are reactions against people who are said to be good news. According to A. Barrère [5], attitudes of opposition to school exist, drawing their sources from disappointments or reactions to contempt or academic humiliation in the broad sense. Therefore, we must understand this attitude of weak students as a reaction to academic despair in which good students are often collateral victims. Faced with a bad mark, the pupils try to "keep their head" by displaying indifference or a feigned carelessness, and logic of "show off" where, losing control, they are "obliged", not to derogate from their reputation, to hold the rank of agitator or leader of disorder [11].

For students who have deficiencies in certain subjects and still believe in school, good students' pressure meets a need for support. They want to take advantage of promising students to learn, if not cheat and get good grades on homework. A student in the 3rd year of the private school stated: "If you are strong in physics, for example, during homework, he asks you to write the answers on a piece of paper for him. If you refuse to give the answers, he can hit you afterwards." [Interview, December 2015]. In this sense, we can see violence in schools because some students encounter it in assessments afterwards.

The school is an institution, which knows a competition between the pupils. Therefore, still believing in school, these "bad students" want to get the grades that lead to diplomas and, later, professional integration. Their behavior is a positioning strategy in the socioeconomic universe and not merely a desire to compete with peers. They want to use violence to become good students and improve their place in the rankings.

\section{Manifestations of School Incivility and Resistance Strategies}

The rites of integration and the formation of clans in the school environment are factors in incivility. Incivility is manifested through acts that can lead to violence. Besides, faced with the rise of incivility, students are developing adaptation and resilience strategies.

\subsection{Events}

Incivility in schools in Ouagadougou is expressed through the imposition of limits on students and racketeering.

\subsubsection{The Racket}

In school paradigms, racketeering involves removing a student's property using symbolic and physical violence. Racketeering is present in schools in the city of Ouagadougou. Some clans practice it-these demand from students payment for goods and services against peaceful school attendance. Students who accept racketeering demands enjoy the clans' protection and may even have the privilege of provoking and abusing other students. On the other hand, the clan harasses those who refuse to racketeer in the schoolyard and even in town.

If you refuse to buy what he asks, he will insult or hit you every time in front of everyone while the teachers are away. During recess, you cannot walk around as wished. Even on the way to school, he will not leave you. [1st-year student, Lycée Nelson Mandela, January 2016].

The playgrounds in the establishments constitute specific societies with their rules, their modes of regulation, and their leaders. The conflict is permanent there, and each actor needs to be reassured. Feeling protected in this uncertain world is crucial that some students voluntarily decide to pay for their safety. They take the initiative to reach out to groups they consider to be stronger and protect them from other groups. Thus, they approach the students who make the law in the playgrounds, buy them bread, cigarettes, drinks. In return, they benefit from the "strong" attention and can go about their school activities with confidence. Racketeering has a more violent side. Unlike classic racketeering, in which there is a form of preliminary negotiation, the action is brutal in this form. The racketeer snatches the property from his victim and proceeds to a sort of auction in front of his comrades.

He asked for my cell phone to listen to music. In the meantime, he takes my chip off, puts it back on me, and tells me it is closed. Then he takes out the battery and asks the students who are stopped opposite, "who wants to buy?" Moreover, a student says he can buy for 200F. Another said he wants the facade, but she asked to follow him to the repairperson since he could not peel it [3rd-year student, Windsor private school, December 2015].

Victims of racketeering suffer double violence: they lose property and money due to verbal and often physical violence but must also remain in the dark. No one should know that a student has been the victim of racketeering. In this logic, denouncing racketeering acts means condemning oneself and suffering acts of violence throughout the year. The conviction is essentially the ban on going to specific spaces in the playground and even in the city. The refusal of racketeering leads the organizers of this behavior to engage in other forms of oppression.

Students know that these incivility acts are prohibited in schools and may be subject to sanctions, but they believe that certain behaviors are important in their training. The pupils know the authorized behaviors because, at the beginning of the school year, the establishments' heads read and explain the Internal Regulations in front of them. The perpetrators of racketeering, knowing that they can be punished if the establishment's officials are informed of their behavior, use threats to keep their victims in the dark.

\subsubsection{The Exercise of Command and Curfew}

School is a space for depositing, welcoming, and developing instinctual violence [12]. In this space, many students want to show that they have more authority than others. They determine areas in the school grounds over 
which they exercise "command". The most emblematic of these commands is "customs." A virtual command post boards students who are not members of the commander's party. Customs can decide to collect a student's bicycle, phone, or bag. Once your property is seized, you have to pay a "fee". One has the impression that one is dealing with a police force that punishes deviant behavior. The keepers of the customs house want to show other students that the establishment has "owners" and standards. Therefore, no one can access it without submitting to the laws. Customs are invisible; none can indicate the location of the customs post. Only the targeted students know where the "formalities" are completed before entering or leaving the school.

Students who refuse to submit to the command are given a curfew. The curfew is a sanction against students who refuse to obey the commandment, which prohibits them from the playground during the break. It can also consist of defining "no-go zones" on their way to school. Any refusal to comply with these guidelines is subject to reprisals or stiffer penalties. A third-year student at the Lycée Mixte de Gounghin, a victim of a curfew, recounts the reality of this violence:

"We can tell you not to take such and such a road when you go to school. Then they know that this is the only way for you. If you force yourself to go the way, they will hit you every day they meet you." [Interview, February 2016].

Faced with the many deprivations of liberty, the victims of incivility do not sit idly by; they develop strategies that may or may not be effective.

\subsection{Resilience Strategies}

The rise in incivility and violence in the school environment leads to resilience strategies that I classified into two main categories: opposing force or rallying to "have peace"

\subsubsection{To Pretend to Be a Boss to Be at Peace}

In an insecure environment, the strategy to avoid permanent violence is to "pretend to be tough." By adopting such an attitude, the victim shows the provocative comrades that he can also be capable of violence, but above all, warns them against continuing their actions. This is the substance of the following statement:

To avoid being mistreated each time, you have to be severe. So you have to show them that you can also do evil, be violent, and even more than what they do. You don't laugh a lot; you talk dirty, you threaten, etc. Like that, they will respect you. Because if they notice that you are shy, you are screwed. [Interview, 3rd-year student, Lycée Sainte Collette, March 2016].

Through this statement, it should be understood that whoever develops this strategy to take shelter must be as rude as his attackers. He must be agitated in the class, in the playground and become threatening towards certain comrades. In the student world, reacting impetuously to provocations from other students or groups of students is seen as a "boy" attitude that refuses to be walked on. It is a logic of questioning forms of domination that is at the basis of this attitude. These attitudes can reduce the pressure and allow a renegotiation of relationships between students.

Moreover, students' pride results from the fact that they have difficulty submitting to other fellow students' will. Therefore, passing off like a boss is a logic of survival in a context where provocation is significant. This strategy also has the advantage of making executioners doubt and reducing their harassment. The students think this is the best strategy for dealing with the incivility and violence that exist in the school environment. Students with violence are reluctant to tempt others who desire assertiveness in their relationship with their classmates. The more the fixed directives are challenged, the more the executioners hesitate to dominate the "non-submissive". However, this strategy can have unintended effects in that it can fuel retaliation and, in turn, more violent acts. That is why some prefer to resign themselves and collaborate with their torturers.

\subsubsection{Comply and Live the Ordeal All Year Round}

The other strategy for dealing with assault is submission. In this situation, the victim agrees to do whatever the abusers ask. The other side of the submission strategy is that the victim decides to negotiate an end to the incivility against him or fraternize with his attackers. The logic is that one day, the latter eventually tire of this follow-up and leave the victim in peace. Many students shine in this type of attitude. As this philosophy teacher puts it:

"The students think that by not responding to the blow of the ass, by not saying anything to those who misbehave towards them, they can end the violence. Some students will not react to insults "[Interview, January 2016].

This strategy is that of students who say they are supporters of "Peace and love". Students in this category are those who are not a member of a group in the school. They opt for silence to put their executioners in front of their conscience to stop incivility towards them. Students who behave in this way become soft and permanent targets for attackers; they are the ones who are forced to buy the bread and juice during recess and often even outside the schoolyard. Therefore, doing nothing in the face of the aggressor is an attitude of resignation that benefits him. Complying with one's diktat can turn into a kind of agreed slavery [10] in which the aggressor uses the victim as he pleases. Indeed, as several students raised during the field survey, the more we accept what the executioner wants, the more he develops desires:

"He can tell you to go buy bread for him and bring back the change and he gave you nothing. There are other same ones; they come to see you every day ". [3rd-year student, Windsor private school, February 2016].

Submission is, therefore, not an effective strategy. Moreover, the students who adopt it are considered "fammelettes" and are the object of mockery. These expressions used to designate them are also vectors of psychological violence. To avoid this degrading term and the mockery that accompanies it, fewer and fewer violence 
victims abide by the rules laid down by the aggressors. They prefer to face their torturers in the hope that the ordeal will not last long.

\section{The Clans, a Protective Necessity in Relations Between Schoolchildren}

If there is one fact about which the debate is less intense in sociology, it is the peer group's existence as a forum for socialization. A. Barrère [10] notes that the relationship to the group as a characteristic of childhood or adolescence is not in itself new. She notes that historians have shown how youthful socialization is the site of integrative rites, taking the form of rituals tolerated in villages or Saturday evening balls, collective heckling or school resistance. Clans are a reality in the school environment, which is essentially an environment of children and adolescents. The students are organized into rival groups. Whether in the classroom or the school, groups of students are visible; they are in competition. They walk together, criticize others, and if they are in the same class, they are located in the same row. (Education advisor, Ouagadougou, January 2016).

Groups are indeed a reality, and their logic of demarcation is cultural. A student from Lycee Marien N'Gouabi described the difference between the clans:

"The differences were felt daily through the language, the way of dressing. The occupation of the different spaces in the schoolyard and also during socio-cultural activities." [Interview, January 2016].

Peer socialization is essential in adolescents. Groups are carriers of norms that students pass on to each other through behavior, dialects, and clothing styles. In general, in the Ouagalais school environment, there are groups of diasporas (mostly from the Ivorian diaspora), yôyô (fans of rap and similar music)," faleurs" (smokers), and supporters of chilling (smokers, drinkers beer and show-goers) and neutrals. Each other's behavior is a social fact in the Durkheimian sense, and those who do not share their standards are seen as adversaries. In this opposition of clans, the diasporas are those who are most willing to undertake spectacular actions to gain respect as shown by P. Bianchini and G. Korbéogo [8], "the "diaspos" have often given the image of a certain radicalism in the modes of action. "We can retain in this opposition, desires to be recognized as the" most bawling guys "in the establishment. The clans are opposed to dressing style, success with girls and boys, proximity to teachers, and a lesser extent in class grades. Furthermore, students who are neutrals do not attach to a group permanently. They are strategists whose proximity to groups evolves according to the threats of the moment.

Although the clans are mostly mixed, clans are made up entirely of girls, who compete mainly in a dress with other girls' homogeneous clans. In these clans, the violence is verbal and psychological. Girls do not hesitate to make fun of their classmates' clothing, their boyfriends. For girls, playgrounds are also an essential place for the production of violence. In this space, they compete on snacks and show off the value of the clothes worn.

In Ouagadougou's school environment, the clans express themselves in the classes, in the playgrounds, as in the neighborhoods. They are illustrated by particular names referring to African resistance, international anarchist and anti-conformist movements, and committed artists. In its presentation of itself, different clans want to be the most visible in the classroom, school, or even in the neighborhood and the city. This permanent competition between the clans helps to create a certain tension in the school environment. The urge to dominate the other is so strong in the lineages that it makes permanent conflicting relationships between the clans. In the life of groups, there are connections between many of them. The goal of these multiple alliances is to hold on to the dominance of other groups. The logic of forming clans at school is based on one of the principles of associative life, which stimulates people's desire to be together. J-C. Bardout [13] believes that their benefit is the realization of collective projects, individual development, and social ties.

In the case of school clans, the group's benefit is linked to "assurance of non-aggression" and respect for members of other groups. This is what can be learned from the description of the life of these groups made by this secondyear student at the Lycée Marien N'Gouabi: "they want to create a family among themselves, they make their plan among themselves, and they organize outings. They stand together, and if there is a problem, they support each other. The group does not let any of its members be looked down upon; they will always stand up for them even if they are not right." [Interview, January 2016]. Student groups present themselves as a universe where games are cleverly constructed around regulations that each actor tries to capitalize on for their school safety. While some use them as a springboard to be noticed in the playground, they are a safety tool for others.

\section{Conclusion}

Life in the post-primary and secondary schools, private and public, of Ouagadougou's city is punctuated by the opposition between groups of students, defiant actions of groups, provocations, reprisals, punitive raids. Paradoxically, the students are not amazed by these incivility acts and even wish that some of them no longer be subject to sanctions by the Internal Regulations. Listening to the students, one does not perceive a feeling of insecurity in them, even among those who have already said they have been victims of verbal or physical violence. We can see that violence in schools is involved and manifests itself in various ways. We can postulate with J. D. Lompo \& al. [14] that the school environment appears more and more a place of deviance where violence tends to become a mode of expression of relationships between young children. Acts of transgression are thus numerous and participate in the diversity of incivilities. Paradoxically, the offence is essential in the 
construction of a school cognitive subject. This needs a permanent transgression of school rules. Beyond acts of extreme violence, the incivilities observed at school are essential behaviors in students' socialization.

\section{References}

[1] Ndiaye L., (2014), Culture, crime et violence, Paris, L'Harmattan.

[2] OUATTARA F., (2020), Éduquer, c'est humaniser. Dignité, intégrité, laïcité et violence, Paris, L'Harmattan.

[3] COSLIN P. G., (2015), «Violences et incivilités au collège», L'orientation scolaire et professionnelle URL: http://osp.revues.org/1060, consulté le 09 octobre 2015.

[4] CHARLOT B. \& EMIN J-C., (1997), Violence à l'école: état des savoirs, Paris, Armand Colin.

[5] BARRÈRE A., (2002), «Un nouvel âge du désordre scolaire: les enseignants face aux incidents», Déviance et société 1/2002 (Vol. 26) 3-19.

[6] LOMPO J. D., 2009, «Les enjeux de la violence en éducation des recherches en Afrique », International journal of violence and school, 10 (version en français), p. 116-130.
[7] DEROUET J-L., 1989, «L'établissement scolaire comme entreprise composite», BOLTANSKY et THEVENOT Justesse et justice dans le travail, Cahiers du centre d'Études de l'Emploi, Paris, PUF, pp. 11-41.

[8] BIANCHINI P. et KORBEOGO G., 2008, «Le syndicalisme étudiant, des origines à nos jours: un acteur permanent dans l'évolution socio-politique du Burkina Faso», JHEA/RESA Vol. 6, Nos. 2\&3, pp. 33-60.

[9] SORY I., 2012, «L’Université de Ouagadougou: territoire de la contestation et de la répression des étudiants», JHEA/RESA vol. $10, \mathrm{n}^{\circ} 1$, p. $171-194$.

[10] BARRÈRE A., 2013, École et adolescence. Une approche sociologique, Bruxelles, De Boeck.

[11] DUBET F. \& MARTUCCELLI D., 1996, À l'école: Sociologie de l'expérience scolaire, Paris, Seuil.

[12] DERIVOIS D., 2006, «Le trajet de la violence à l'école, un point de vue clinique» Revue de recherches en éducation, n³7, pp. 39-48.

[13] BARDOUT J-C., 1984, Guide du dirigeant d'association, Paris Seuil.

[14] LOMPO J. D., BARY H. F., HENRY P. E. et BOLY D., 2009, Étude sur les violences basées sur le genre en Milieu scolaire au Burkina Faso, MERSS/MEF, Ouagadougou. 